\title{
Immunoglobulin $\kappa$ Light Chain Variable Region Gene Complex Organization and Immunoglobulin Genes Encoding Anti-DNA Autoantibodies in Lupus Mice
}

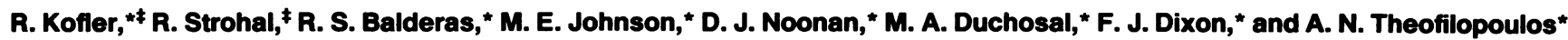 \\ *Department of Immunology, Research Institute of Scripps Clinic, La Jolla, California 92037; and ${ }^{\ddagger}$ Institute for General and \\ Experimental Pathology, University of Innsbruck, A-6020 Austria
}

\begin{abstract}
We have investigated the genetic origin of autoantibody production in several strains of mice that spontaneously develop a systemic lupus erythematosus-like disease. Restriction fragment length polymorphism analyses of gene loci encoding $\boldsymbol{k}$ light chain variable regions (Igk-V) demonstrated, as shown previously for the Ig heavy chain locus, that autoantibody production and disease occur in different $I g k-V$ haplotypes. Moreover, autoimmune mice with known genetic derivation inherited their Igk-V loci essentially unaltered from their nonautoimmune ancestors. New Zealand black lupus mice, with unknown genetic derivation, had a possibly recombinant $I g k-V$ haplotype, composed of $V_{k}$ loci that were primarily indistinguishable from those of nonautoimmune strains from either of the two potential donor haplotypes. The heavy and light chain gene segments (variable, diversity, joining) encoding antiDNA antibodies were diverse and often closely related, or even identical, to those found in antibodies to foreign antigens in normal mice. Only 1 of 11 sequenced variable region genes could not be assigned to existing variable region gene families; however, corresponding germline genes were present in the genome of normal mice as well. These data argue against abnormalities in the genes and mechanisms generating antibody diversity in lupus mice and suggest a remarkable genetic and structural diversity in the generation of anti-DNA binding sites.
\end{abstract}

\section{Introduction}

Systemic lupus erythematosus and related chronic inflammatory disorders in humans and mice are closely associated with, and possibly mediated by, circulating immune complexes that deposit in various organs and cause tissue damage and disease. At least part of the antibodies involved in immune complex formation react with DNA and other self-antigens, which has led to the notion that these diseases are autoimmune in nature. Cell transfer studies in murine model systems have further suggested that the underlying defect resides within the immune

This study was presented in part at the Annual Meeting of the Federation of American Societies for Experimental Biology, 2 April 1987, Washington, DC, and published in abstract form (1987. Fed. Proc. 46:1368a).

Address reprint requests to Dr. Kofler, Scripps Clinic and Research Foundation, 10666 North Torrey Pines Road, La Jolla, CA 92037.

Received for publication 4 December 1987 and in revised form 27 April 1988 .

J. Clin. Invest.

(C) The American Society for Clinical Investigation, Inc.

0021-9738/88/09/0852/09 \$2.00

Volume 82, September 1988, 852-860 system. However, in spite of intensive investigations (reviewed in reference 1), the exact cellular and molecular abnormalities leading to B cell hyperactivity and autoantibody production are still unknown. As suggested by the occurrence of similar antibodies in normal individuals $(2,3)$, the autoantibodies expressed in these diseases may be normal components of the immune system that become pathogenic when expressed at high levels and for extended lengths of time, possibly because of defective immune regulatory circuits, potent polyclonal or antigenic stimulation, or insufficient immune complex removal. Alternatively, disease-associated autoantibodies may differ from those found in normal subjects and result from abnormalities in the complex mechanisms generating antibody diversity (reviewed in references 4 and 5), including abnormal Ig germline genes, defective selection of variable (V) ${ }^{1}$ and diversity (D) gene segments during generation of the preimmune repertoire, or defects in somatic antibody diversification. These not necessarily exclusive possibilities can be distinguished by analyzing the genetic origin of disease-associated autoantibodies. Such studies also address the primary structure of autoantibodies, their clonal derivation, and the contribution of somatic events to their diversification as well as provide information about inducing agents, the developmental stage at which B cells acquire self-specificity, and the structural relatedness among such antibodies.

Corresponding studies have been initiated in murine lupus models and have provided considerable insights into the genetic origin of autoantibodies (reviewed in references 6 and 7). Thus, the Ig heavy chain variable region gene complex (Igh-V) of autoimmune mice investigated thus far appeared normal by restriction fragment length polymorphism (RFLP) criteria, and the disease is not associated with a particular Igh- $V$ haplotype (8-10). However, possible associations with Ig $\kappa$ light chain variable region gene complex (Igk-V) haplotypes or with abnormalities in the $V_{k}$ germline gene repertoire remain to be determined. The gene segments encoding the autoantibodies that typify lupus mice (anti-DNA, anti-Ig [rheumatoid factor, RF], antihistone) have also been investigated. Our nucleic acid sequence analyses revealed that such molecules may be encoded by a variety of $\mathrm{V}, \mathrm{D}$, and $\mathrm{J}$ (joining) gene segments, most of which were closely related to those found in antibodies to exogenous antigens $(11,12)$. Although these findings argued against abnormalities in the generation of autoantibodies, they provided only limited information about the individual antiself response characteristics, since only a single prototype was analyzed for each of the above specificities. Recently, genetic restriction has been reported for antibromelaine-treated red

1. Abbreviations used in this paper: $\mathrm{C}$, constant; D, diversity; Igh-V, Ig heavy chain variable region gene complex; $I g k-V, \mathrm{Ig} \kappa$ light chain variable region gene complex; J, joining; $R F$, rheumatoid factor; RFLP, restriction fragment length polymorphism; V, variable. 
blood cell antibodies (13) and for RF from nonautoimmune (14) and lupus mice (15), although results with regard to the latter type of autoantibodies are controversial (16). Somewhat restricted $V_{H}$ gene usage has also been suggested by Ig gene rearrangement analysis of anti-DNA-producing hybridomas (17), however, only a small number of murine anti-DNA nucleic acid sequences have been reported $(11,18,19)$ and more information regarding the genetic origin of this important anti-self response is clearly needed.

The present study describes the organization of the $I g k-V$ gene complex in lupus mice and defines gene segments encoding sevt ral lupus-associated anti-DNA autoantibodies. Using RFLP : Inalysis, we determined the $I g k-V$ haplotypes of all major upus strains and showed that lupus disease is not associated vith a particular I $g k-V$ haplotype, and that abnormalities in the $V_{\kappa}$ germline gene repertoire do not appear to be a prerec uisite for autoantibody production and disease development. Subsequently, the gene segments encoding monoclonal anti- JNA heavy and light chains from MRL-lpr/lpr and $(\mathrm{NZF} \times \mathrm{W}) \mathrm{F}_{1}$ lupus mice were determined by cDNA cloning and tucleic acid sequence analysis. The six monoclonals (five anal /zed in this study and one previously) were encoded by five different $V_{H}$ genes from two $V_{H}$ gene families and $V_{\alpha}$ genes from at least four families (one light chain sequence was not determined) along with several $D$, all $J_{H}$, and three of the four known functional $\mathbf{J}_{\boldsymbol{\alpha}}$ gene segments. Their sequences were closely related, or even identical, to those of corresponding segments from antibodies to exogenous antigens in normal mice. Only the $\mathrm{V}_{\mathbf{H}}$ gene expressed in an MRL-lpr/lpr antiDNA could not be assigned to existing $V_{H}$ gene families. However, the germline gene organization of this small family in lupus and $I g h-V$ haplotype-matched nonautoimmune mice was indistinguishable by RFLP analysis.

\section{Methods}

Mouse strains. The genetic origins, histologic, cellular, and humoral characteristics of the various murine lupus strains have been reviewed (1). Mice were bred and maintained at the Scripps Clinic and Research Foundation Mouse Colony.

RFLP analysis. High molecular weight liver DNA (20) was digested with restriction enzymes (BamHI, PstI, HindIII, EcoRI), sizeseparated on agarose gels, transferred to Zetabind filters (Cuno Inc., Meriden, (CT) and hybridized to ${ }^{32} \mathrm{P}$-labeled DNA probes as previously described (8). The filters were washed repeatedly, including a wash in $0.2 \times$ standard saline citrate (SSC, $1 \times$ SSC: $150 \mathrm{mM} \mathrm{NaCl}, 15 \mathrm{mM}$ Na-citrate, $\mathrm{pH} \mathrm{7.0)}$ at $65^{\circ} \mathrm{C}$ for $30 \mathrm{~min}$, and exposed to XAR film with amplifying screen for $1-7 \mathrm{~d}$. Filters were reused after probe removal by a 30-min incubation at $42^{\circ} \mathrm{C}$ in $0.4 \mathrm{M} \mathrm{NaOH}$ followed by neutralization in $0.1 \times \mathrm{SSC}, 0.1 \% \mathrm{SDS}, 0.2 \mathrm{M}$ Tris- $\mathrm{HCl}$, pH 7.5, at $42^{\circ} \mathrm{C}$.

DNA probes for $V_{H} 9$ (VGAM3.8 [21]), $V_{k} 8$ (22), $V_{k} 10$ (23), $V_{\kappa} 12-13$ (24), and $V_{\kappa} 19(25)$ have been described. A genomic subclone containing the entire $T 15 \mathrm{~V}_{k} / \mathrm{J}_{k} 5(26)$ and MPC167 $\mathrm{V}_{k} / \mathrm{J}_{k} 5(27)$ rearrangement was provided by $S$. C. Riley as probes for the $V_{k} 22$ and $V_{k} 24$ families, respectively. The following probes were generated in our laboratory by subcloning cDNA fragments into $\mathrm{pBS}-\mathrm{M} 13^{+}$(Vector Cloning Systems, San Diego, CA): $\mathrm{V}_{\mathrm{H}} \mathrm{DNA} 4$, a PstI fragment corresponding to the entire MRL-DNA4 $V$ region-this probe defines a new $V_{H}$ gene family (28), termed $V_{H} 10 ; V_{k} 1$, a DdeI fragment encoding the MRLDNA10 $\mathrm{V}_{\alpha}$ region from the $5^{\prime}$ untranslated region to codon 80 (11); $V_{k} 2$, a Sau3A fragment encoding a portion ( $5^{\prime}$ untranslated region to codon 66) of the BXW-DNA14 light chain; $\mathrm{V}_{k} 5$, an Avall fragment ( $5^{\prime}$ untranslated region to codon 68) of the MRL-DNA22 light chain cDNA; $V_{\kappa} 9$, a Rsal fragment containing the entire BXW-DNA16 V region up to codon 95 (sequences for the latter four probes are reported here); $\mathrm{V}_{\kappa} 21$, an AvalI fragment ( $5^{\prime}$ untranslated region to codon 57) from the nonfunctional transcript of the P3-X63-Ag8.653 myeloma line (29); $V_{\kappa} 28$, a PstI-MnlI fragment encoding the entire $V$ region up to codon 100 of the MRL-RF28 light chain (Kofler et al., manuscript submitted for publication).

Generation and specificity of hybridoma autoantibodies. Hybridoma cell lines originated from fusions of untreated female MRL-lpr/lpr and $(\mathrm{NZB} \times \mathrm{W}) \mathrm{F}_{1}$ mouse spleen cells with the BALB/c nonsecretor myeloma cell line P3-X63-Ag8.653, as previously detailed (30). Supernatants were screened for reactivity with single-stranded DNA by ELISA (31), and positive colonies were subcloned to establish monoclonality by limiting dilution. Three MRL-lpr/lpr and three (NZB $\times \mathrm{W}) \mathrm{F} 1$ hybridomas were included in this study. Ig isotypes of subcloned hybridoma supernatants were determined by subclass-specific ELISA. Supernatants with defined Ig content were assayed for binding to single-stranded DNA, synthetic polynucleotides, dextran sulfate, heparan sulfate, protamin sulfate, cardiolipin, histones, and mouse Ig in a direct binding ELISA as described (31). Briefly, monoclonals were incubated in serial dilutions in the' presence (as a blocking control) or absence of various single-stranded DNA concentrations in microtiter plates containing the immobilized test antigen, and bound Ig detected by subsequent incubation with an enzyme-linked seconqary antibody. Results are expressed as percentage of total autoantibody addèd (determined in parallel by incubation with plate-bound anti-Ig antibodies) that is specifically bound to the test antigen. This percentage reflects the relative affinity of the autoantibody to the various test antigens. Reactivity with double-stranded DNA was determined by indirect immunofluorescence on Crithidia Luciliae (Quantafluor, Kallestad Laboratories, Austin, TX).

cDNA cloning and nucleic acid sequencing. CDNA libraries were prepared following the Okayama-Berg cloning procedure (32). cDNA clones corresponding to Ig mRNAs were identified by hybridization to heavy and light chain constant (C) region DNA probes of the respective Ig isotype and sequenced by partial chemical degradation as described (11). 5-20 heavy and light chain encoding clones were recovered from each library and subjected to nucleic acid and/or restriction enzyme analysis. All reported sequences derive from at least two independent cDNA clones and were determined for both coding and noncoding strands.

Computer-aided sequence comparisons. The nucleic acid and deduced amino acid sequences were compared with Ig sequences from the Genetic Sequence Data Bank (Genbank), the National Biomedical Research Foundation Database, and additional sequences not yet contained in these collections using the MicroGenie Sequence Analysis Program (33) (Beckman Instruments, Inc., Palo Alto, CA).

\section{Results}

\section{Igk-V gene complex of lupus mice}

The structural genes encoding Ig heavy and light chain $\mathrm{V}$ regions show polymorphism among inbred strains of mice (34, $35)$. To determine possible $I g k-V$ haplotype associations and to scrutinize $\mathrm{V}_{\mathrm{k}}$ gene loci for possible irregularities that might contribute to autoantibody generation, we subjected DNA from all major lupus mice, their ancestors (if known), and other nonautoimmune control strains to RFLP analysis using four restriction enzymes and DNA probes corresponding to 12 $\mathrm{V}_{\kappa}$ gene families (Fig. 1). DNA from MRL-lpr/lpr mice whose genome originated from $\mathrm{LG} / \mathrm{J}, \mathrm{C} 3 \mathrm{H} / \mathrm{Di}, \mathrm{AKR} / \mathrm{J}$, and C57BL/ 6 , resulted in the same patterns as that from the ancestral AKR/J strain (haplotype $a$ ) with all probes tested. BXSB lupus mice (like their two nonautoimmune ancestors C57BL/6 and $\mathrm{SB} / \mathrm{Le}$ ) and NZW were haplotype $b$. NZB also produced a haplotype $b$-like pattern with probes for $\mathrm{V}_{\kappa} 5,8,10,12-13,19$, 21,22 , and 28 . However, probes for families $V_{\alpha} 1,2,9$, and 24 

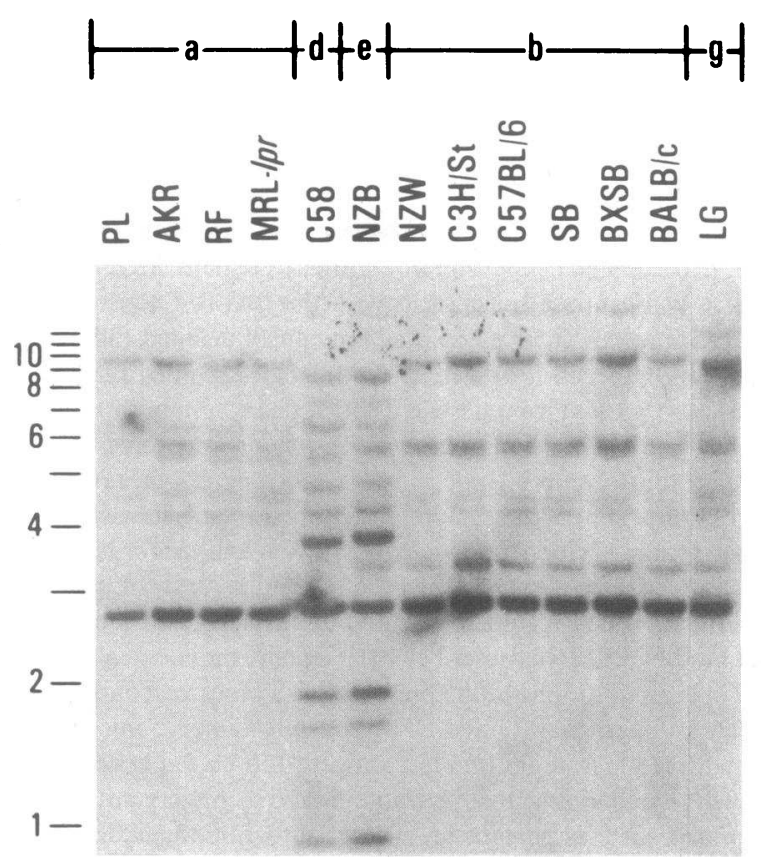

${ }^{x}$
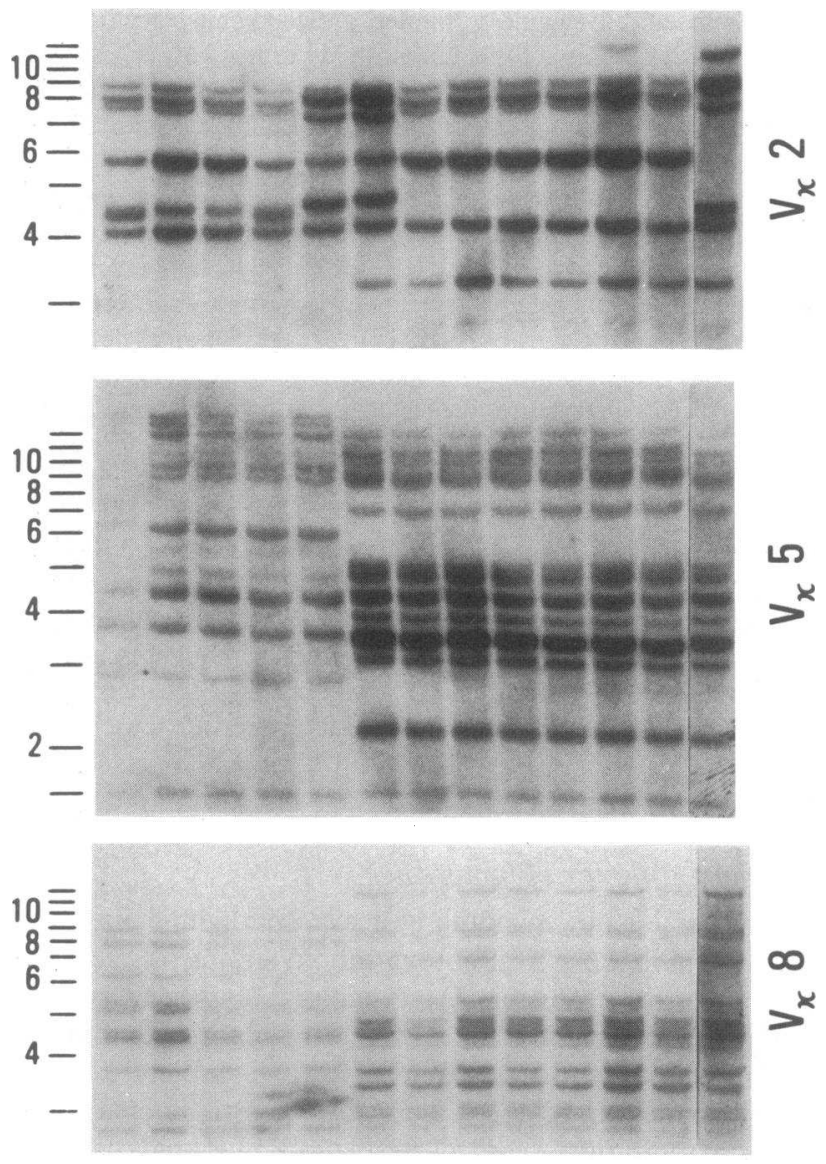

Figure 1. Autoradiographs of restriction enzyme-digested, size-separated liver DNA from several lupus and other inbred strains of mice probed with ${ }^{32} \mathrm{P}$-labeled DNA corresponding to $12 V_{k}$ gene families. Lower case letters between bars above strain designation indicate Igk- $V$ haplotypes as defined by RFLP analysis (see Note Added in Proof), 1-kb size markers are on the left, and $\mathrm{V}_{\mathrm{k}}$ probes are on the right of each blot. Shown are HindIII digests except for $V_{\kappa} 10, V_{\kappa} 28$

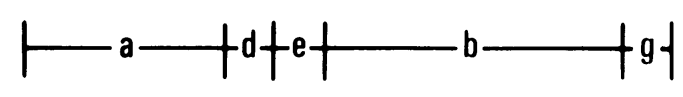

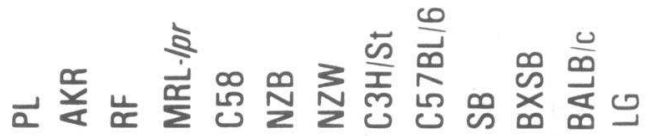
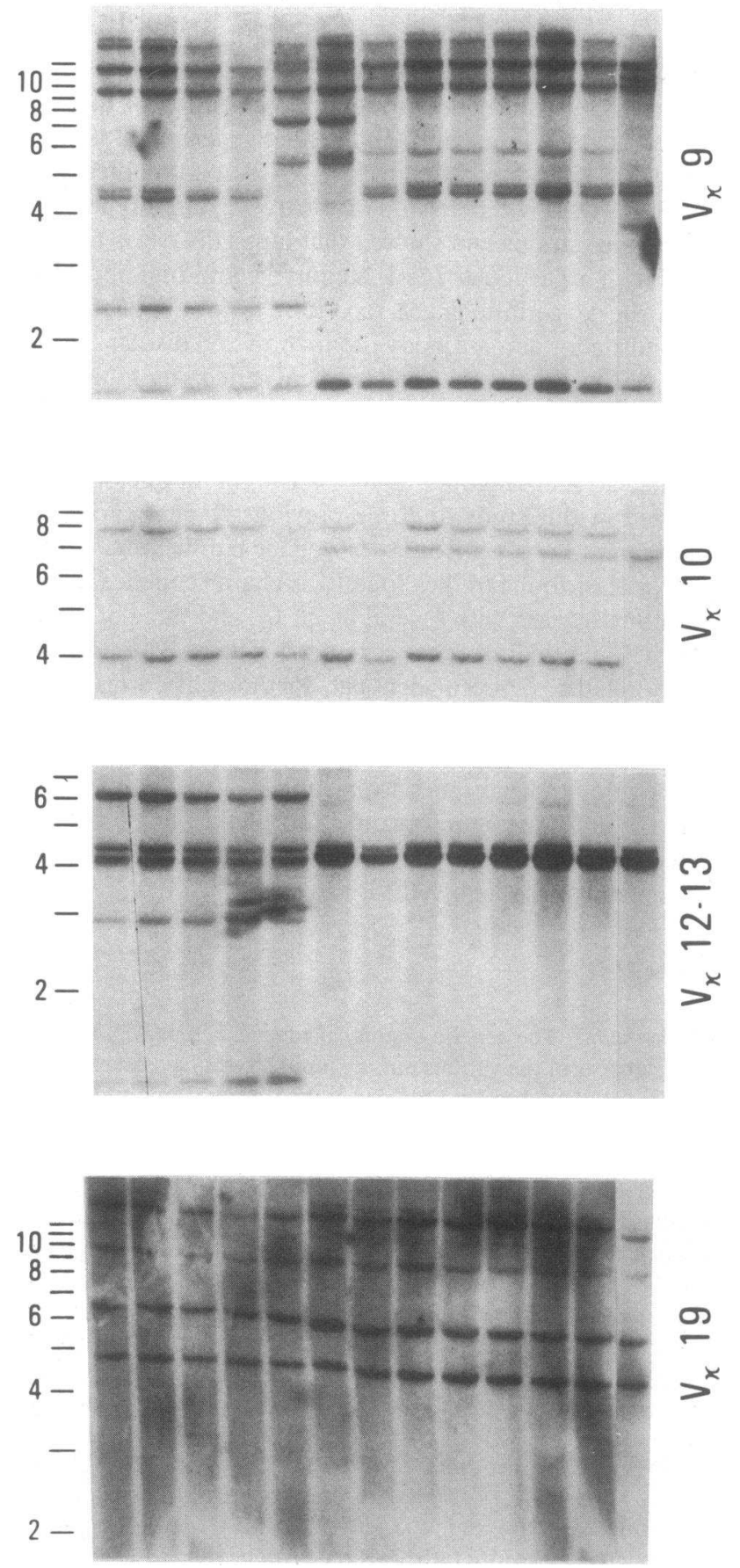

(both PstI), and $\mathrm{V}_{\alpha} 19$ (BamHI). However, in all instances, four restriction enzymes (BamHI, EcoRI, PstI, HindIII) have been used with results leading to the same conclusions as derived from the presented examples. The additional restriction fragment in the BXSB lane on the $\mathrm{V}_{\alpha} 2$ blot that is not present in other haplotype $b$ lanes was not seen in DNA from 14 other BXSB mice analyzed in analogous fashion for a control and is probably artificial. 

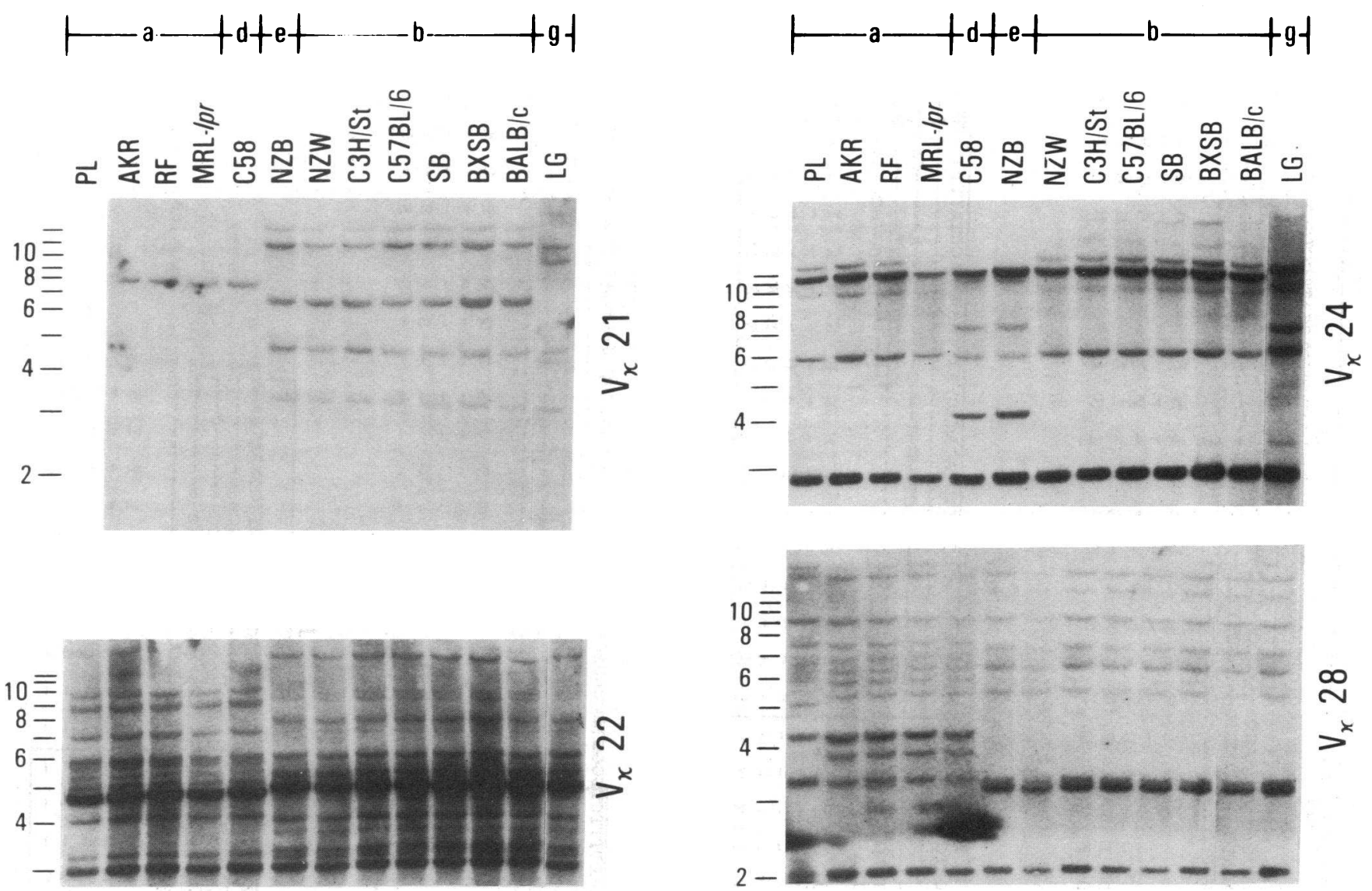

Figure 1 (Continued)

detect a pattern clearly different from haplotype $b$ but very similar to that seen with C58 mouse DNA. The unique C58 and NZB haplotypes are referred to as $d$ and $e$, respectively.

\section{Structural genetic elements encoding anti-DNA autoantibodies}

To define the structural genetic elements (V/D/J gene segments) encoding autoantibody heavy and light chains, cDNA clones encoding MRL-lpr/lpr and $(\mathrm{NZB} \times \mathrm{W}) \mathrm{F}_{1}$ hybridoma
anti-DNAs were prepared and their nucleic acid sequences were determined. The isotypes and fine-specificities of the respective monoclonals are depicted in Table I. Their nucleic acid and deduced amino acid sequences up to the $C$ regionencoding portion are shown in Fig. 2 along with the previously analyzed MRL-DNA10 antibody (11). The sequences were then compared with published Ig genes to determine their relationship to genes used in exogenous responses in normal mice.

Table I. Origin, Isotypes, and Fine Specificities of Murine Lupus Anti-DNA Autoantibodies*

\begin{tabular}{|c|c|c|c|c|c|c|c|}
\hline \multirow[b]{2}{*}{ Clone $^{\ddagger}$} & \multirow[b]{2}{*}{ Isotype } & \multicolumn{5}{|c|}{ Reactivity } & \multirow[b]{2}{*}{ dsDNA } \\
\hline & & ssDNA & poly-dT & poly-dU & poly-dI & poly-I & \\
\hline & \multicolumn{7}{|c|}{$\%$} \\
\hline MRL-DNA10 & IgM & 100 & 60 & 0 & 10 & 0 & - \\
\hline MRL-DNA22 & IgM & 77 & 67 & 0 & 1 & 0 & + \\
\hline MRL-DNA4 & $\operatorname{IgG} 2 a$ & 51 & 46 & 2 & 42 & 0 & - \\
\hline BXW-DNA7 & IgM & 100 & 69 & 0 & 4 & 0 & - \\
\hline BXW-DNA14 & IgM & 93 & 100 & 0 & 16 & 15 & - \\
\hline BXW-DNA16 & IgM & 42 & 43 & 0 & 55 & 0 & - \\
\hline
\end{tabular}

* Reactivity is expressed as percent of total added autoantibody that is bound by the respective substrate. Specificity of reactions was confirmed by inhibition experiments with fluid-phase single-stranded (ss)DNA. The percentages indicated are means of two to three dilutions; standard deviations were usually less than $20 \%$ of mean (not shown). No reactivity was observed with the additional substrates listed in Methods. Reactivity with double-stranded (ds)DNA was determined by indirect immunofluorescence on Crithidia luciliae kinetoplasts. ${ }^{\ddagger}$ MRL-DNA10 and 22 (same fusion) and MRL-DNA4 were derived from 3.5-mo-old MRL-lpr/lpr females. All BXW-DNA clones were derived from a 6-mo-old $(\mathrm{NZB} \times \mathrm{W}) \mathrm{F}_{1}$ female. 

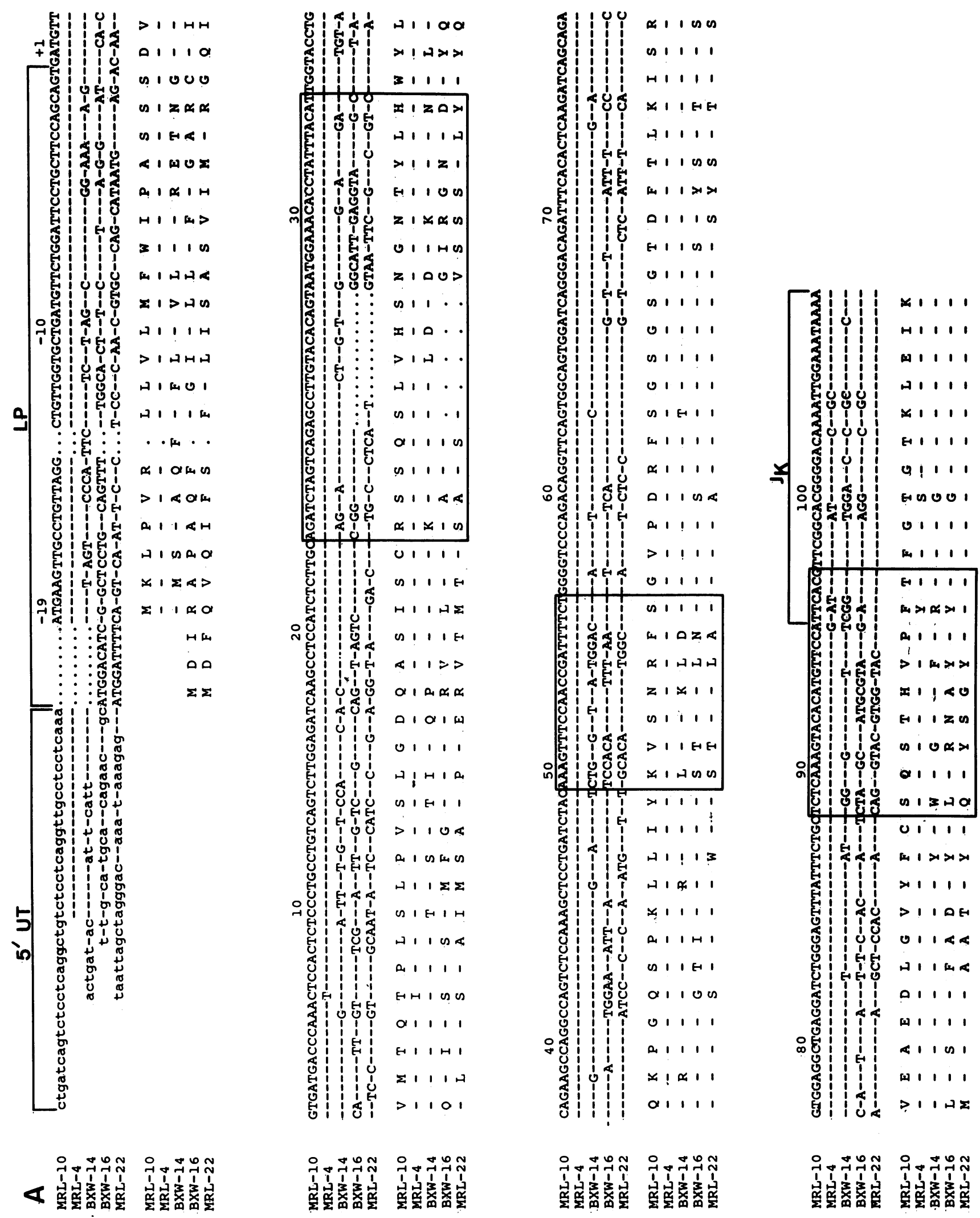

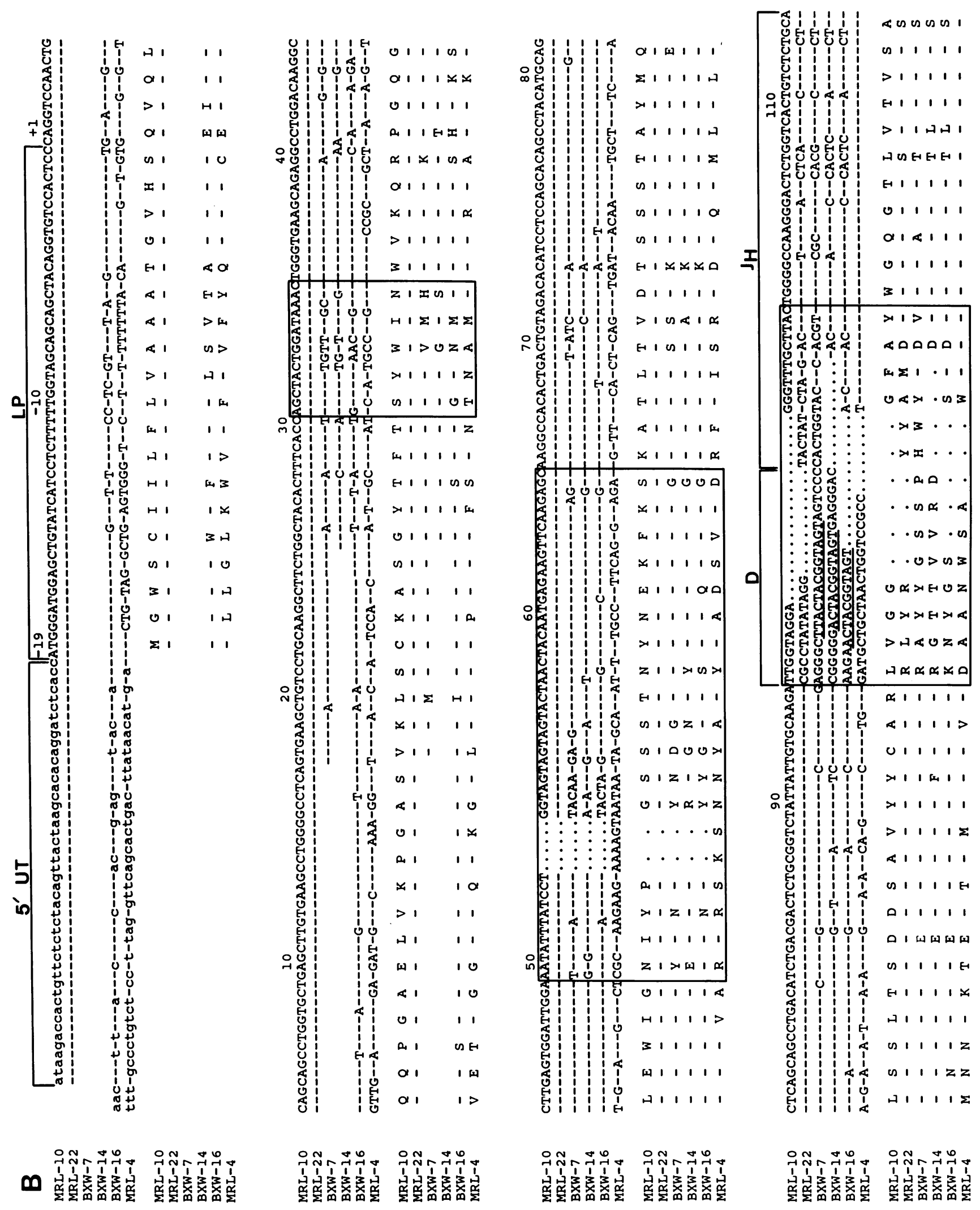

E I n I I os

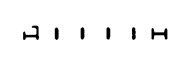

$\begin{array}{llllll}-1 & 1 & 1 & 1 & 1\end{array}$
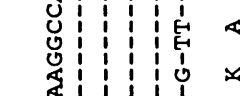

《1 1114

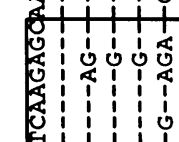

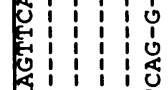

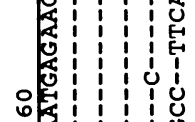

$\forall \begin{array}{lllll}1 & 1 & 1 & 1\end{array}$

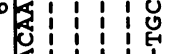

E

E

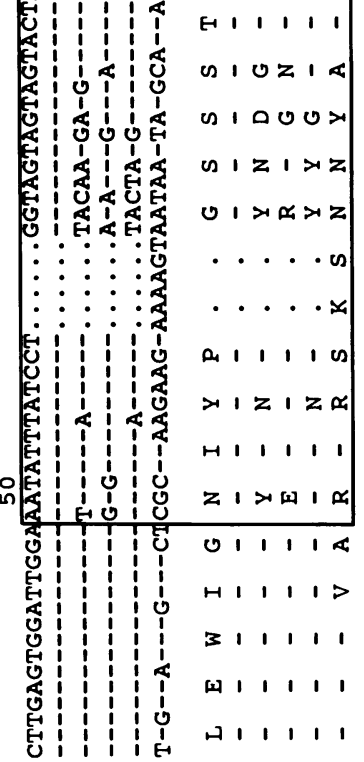

$\begin{array}{llllll}4 & 1 & 1 & 1 & 1 \\ 4 & 1 & 1 & 1\end{array}$

$x+1110$

स 11 \%

211114

$71+101$

$z 11>0 s$ 
Light chain genes. The MRL-DNA4 $\mathrm{V}_{k}$ gene encoded sequence differed from the MRL-DNA10 prototype and the identical BALB/c $V_{k} 1 \mathrm{~A}$ germline gene (36) by a single nucleotide change. The $V_{k}$ gene encoding anti-double-stranded DNA antibody MRL-DNA22 was assigned to the $V_{\kappa} 5$ family, differing from the BALB/c germline gene $\mathrm{H} 1$ (37) by only five nucleotides. The BXW-DNA14 $\mathrm{V}_{k}$ gene segment was identical to that of a C57BL/6 antidextran antibody (42.4B.12 [38]), and an antiarsonate amino acid sequence (1270.7 [39]) of the $\mathrm{V}_{x} 2$ family (40). For the BXW-DNA $16 \mathrm{~V}_{\kappa}$ gene, only a $88 \%$ match was found in the data base $\left(a V_{k} 9\right.$ gene encoding an anti-[anti- $\left(\mathrm{Glu}^{60} \mathrm{Ala}^{30} \mathrm{Tyr}^{10}\right)_{n}$ antibody [41]). Hence, with the possible exception of BXW-DNA16, all anti-DNAs expressed $V_{k}$ genes that encode responses to exogenous antigens as well. MRL-DNA4 and MRL-DNA22 $\mathrm{J}_{\kappa}$ segments differed from the BALB/c germline $J_{k} 2$ and $J_{\kappa} 4$ germline sequences (42) in three and two positions, respectively. The same differences were observed in other MRL-lpr/lpr $\mathrm{J}_{\mathrm{k}}$ segments previously $(8,43)$, and are probably allelic. The $\mathrm{J}_{\kappa} 1$ and $\mathrm{J}_{\kappa} 2$ segments expressed in BXW-DNA14 and BXW-DNA16, respectively, were identical to the corresponding BALB/c germline gene segments.

Heavy chain genes. All $\mathrm{V}_{\mathrm{H}}$ genes, except that of MRLDNA4, revealed around or over $90 \%$ similarity to $V_{H}$ genes of the large J558 family: the MRL-DNA22 $\mathrm{V}_{\mathrm{H}}$ gene was identical to that of MRL-DNA10 and showed over $94 \%$ match with $V_{H}$ sequences encoding antibodies to the hapten nitrophenyl (44, 45). The $V_{H}$ genes encoding the $(N Z B \times W) F_{1}$ anti-DNAs 7 , 14 , and 16 had their closest matches in germline genes $V_{H} 23$ (89\% [44]) and $V_{H} 105$ (92\% [46]), and in the 45.21.1a antidextran $V_{H}$ gene (92\% [38]), respectively. The MRL-DNA4 heavy chain was encoded by a novel $V_{H}$ gene that defines a new murine $\mathrm{V}_{\mathrm{H}}$ gene family (28). However, the germline gene organization of this small family in lupus and $I g h-V$ haplotype-matched nonautoimmune mice was indistinguishable by RFLP analysis (data not shown). The putative D segments of the MRL-lpr/lpr anti-DNAs could not be assigned. All three $(\mathrm{NZB} \times \mathrm{W}) \mathrm{F}_{1}$ anti-DNAs expressed $\mathrm{D}$ segments homologous to the BALB/c FL16.1 D gene (47), although in two reading frames, which resulted in quite different amino acid sequences. The $J$ segments in MRL-DNA22 $\left(\mathrm{J}_{\mathrm{H}} 4\right)$, MRL-DNA4 $\left(\mathrm{J}_{\mathrm{H}} 3\right)$, BXW-DNA14 $\left(\mathrm{J}_{\mathrm{H}} 2\right)$ were identical to the corresponding BALB/c germline sequences (48) whereas the BXW-DNA16 $\mathrm{J}_{\mathrm{H}} 2$ segment showed a single silent nucleotide difference in codon 104. The BXW-DNA7 $\mathrm{J}_{\mathrm{H}} 1$ segment differed in two nucleotides (codon 101 and 111) from the corresponding BALB/c germline sequence. These differences may be either allotypic or secondary to somatic mutation.

\section{Discussion}

In this study, we address possible associations of murine lupus with abnormalities in the genes and complex mechanisms generating antibody diversity and analyze genetic and struc- tural requirements for anti-DNA reactivity. We first investigated whether autoantibody production and lupus disease are associated with particular Ig haplotypes or abnormal Ig germline genes. Previous studies have not identified disease associations with any particular $I g h-V$ haplotype, and the $\mathrm{V}_{\mathrm{H}}$ genes of lupus mice appeared normal by RFLP criteria (8-10). This conclusion also appeared to be true for the new $V_{H}$ gene family (28) defined by MRL-DNA4, an anti-DNA autoantibody analyzed in this study (data not shown). Since the Igk-V complex is also polymorphic (35), we tested various lupus and nonautoimmune control strains for RFLPs with $V_{k}$ DNA probes corresponding to $12 \mathrm{~V}_{k}$ groups (40). These probes detect a varying number of restriction fragment patterns in different inbred strains of mice, thus defining several $I g k-V$ haplotypes (Kofler et al., manuscript submitted for publication). As our results show, spontaneous high level autoantibody production and lupus disease occur in different $I g k-V$ haplotypes. Moreover, based upon, and hence within the limitations of, RFLP analysis, our study suggests that the $I g k-V$ gene complex in lupus mice may be essentially normal. This technique can reveal recombinations, gene loss or duplication, and sequence alterations, provided these changes detectably alter the length of restriction fragments hybridizing to the labeled DNA probes. Differences that do not fulfill these requirements (as is frequently the case with small sequence changes and gene conversions) will remain undetected, and yet might contribute to the serological abnormalities associated with this disease. However, the overall lupus autoantibody response employs a large number of $V_{k}$ genes from different families (6) and causal defects (such as lupus-specific $V_{\kappa}$ genes, or sequence alterations in multiple $\mathrm{V}_{\mathrm{k}}$ genes) should have become apparent. Moreover, our conclusion is supported by the lack of cosegregation of autoantibody production and $V_{k}$ allotype in recombinant inbred strains, and by the observation that lupus can be induced in normal background mice (reviewed in reference 6). The combined data provide compelling evidence that defects within the $I g h-V$ or $I g k-V$ germline gene loci appear unlikely causes for autoantibody expression in lupus mice.

We next investigated whether autoantibodies might result from rearrangement of unusual gene segments during generation of the primary antibody repertoire. For this purpose, we compared heavy and light chain sequences from randomly selected anti-DNA autoantibodies from MRL-lpr/lpr and $(\mathrm{NZB} \times \mathrm{W}) \mathrm{F}_{1}$ mice with those of published Igs. The D segments expressed in the MRL-lpr/lpr anti-DNAs could not be assigned to known D mini gene families and hence might correspond to such unusual gene segments. However, the significance of this finding is unclear since novel $D$ segments have been observed in antibodies to exogenous antigens and may be attributed to allotypic differences, uncharacterized $D$ families in the murine genome or excessive alterations during V-D-J joining (49). Moreover, the $\mathrm{D}$ segments in our $(\mathrm{NZB} \times \mathrm{W}) \mathrm{F}_{1}$ anti-DNAs and in the recently reported MRL-lpr/lpr antiDNA autoantibody $\mathrm{H} 130$ (18) could be assigned to known D
Figure 2. (A) Nucleic acid and deduced amino acid sequences of anti-DNA autoantibody light chain $\mathrm{V}$ regions. Dashes in sequence indicate identity to the previously reported MRL-DNA10 sequence (11) in the top line; dots indicate gaps introduced for proper alignment. Complementarity-determining regions are boxed. Amino acid numbering is according to Kabat et al. (52). 5'UT, $5^{\prime}$ untranslated region; LP, leader peptide. (B) Nucleic acid and deduced amino acid sequences of anti-DNA autoantibody heavy chain $\mathrm{V}$ regions. Nucleotides identical to the core sequence of the FL16.1 D segment germline gene (52) are underlined. Remaining legend as for $A$. 
gene families (47). Of interest, the length of the third complementarity-determining region, which is considered important for antigen and antiidiotype recognition, differed from 7-14 residues. All anti-DNA $V$ genes published thus far $(11,18,19$, this report), originated from existing $V_{H}$ or $V_{k}$ gene families except that encoding the MRL-DNA4 $\mathrm{H}$ chain. However, corresponding $\mathrm{V}_{\mathbf{H}}$ genes are present in the germline of normal mice as well, and have been observed in hybridoma antibodies of unknown specificity from lipopolysaccharide-stimulated C57BL/6 splenocytes (Dildrop, R., personal communication). Close similarity, or even identity, was observed with $\mathrm{V}$ genes expressed in response to exogenous antigens, indicating that the same $\mathrm{V}$ genes can be used to encode autoantibodies and antibodies to exogenous antigens.

A question of considerable interest is that of genetic restriction among autoantibodies. While the overall lupus-associated anti-self response appears essentially unrestricted (6), there is increasing evidence for genetic restriction among autoantibodies with a given specificity (13-15), a finding also seen in exogenous responses. Our results and data from the literature suggest that the degree of restriction of the anti-DNA response is low: seven of eight murine anti-DNA $V_{H}$ nucleic acid sequences published thus far (the nearly identical $V_{H}$ sequences encoding four clonally related hybridomas from reference 19 are here considered as one) probably originated from independent germline genes since they differed from each other in 25 to over 50 nucleotides. The six anti-DNA $V_{k}$ genes known to date (five from this report and one encoding four clonally related anti-DNAs [19]) belonged to $V_{k}$ groups $1,2,4,5$, and 9. Moreover, evidence for involvement of additional $V_{H}$ and $\mathrm{V}_{\mathrm{k}}$ families in anti-DNA antibodies has been presented in the literature, including Q52, 7183, S107, $\mathrm{V}_{k} 8, \mathrm{~V}_{\kappa} 19, \mathrm{~V}_{k} 21$ (6). Hence, the variety of $\mathrm{V}$ genes that fulfill the structural requirements of participation in DNA-binding site generation is remarkable. Human monoclonal anti-DNAs can also be encoded by dissimilar $\mathrm{V}_{\mathrm{H}}$ genes (50), although such antibodies may be genetically more restricted in humans than in mice (51). The genetic diversity of anti-DNA autoantibodies agrees with the serologic observation that anti-DNA antibodies recognize a considerable number of different epitopes (31). Additional possibilities may be that many combinations of different $V$ genes can generate similar binding sites, or that quite dissimilar binding sites (with possible additional binding capacities) react with DNA. Clearly, resolving these important issues will require three-dimensional structure analysis of corresponding immune complexes.

Note added in proof. During the processing of this manuscript, another nomenclature for murine $I g k$ haplotypes was proposed (D'Hoostelaere et al. 1988. J. Immunol. 141:652-661). To avoid confusion in the literature, we have adopted this nomenclature and expanded it by adding two additional haplotypes (Kofler et al., manuscript submitted for publication). Hence, haplotypes $e, b$, and $g$, depicted in this publication, have been renamed $b, c$, and $h$, respectively. Haplotypes $a$ and $d$ remain unaltered.

\section{Acknowledgments}

We thank Drs. J. D. Capra, N. Hozumi, P. Leder, R. P. Perry, and S. C. Riley for providing $V_{\kappa}$ probes; Drs. T. M. Aguado, R. Faessler, G. Kroemer, P. A. Singer, and G. Wick for stimulating discussion; C. Amundsen, S. T. Hogan, and K. Joehrer for excellent technical assis- tance; and P. Minick and M. K. Occhipinti for editing and manuscript production.

This is Publication No. 5012IMM from the Department of Immunology, Research Institute of Scripps Clinic. The work reported herein was supported, in part, by National Institute of Health grants AR31203, AR33826, AI07007, AG01743, a grant from the Keck Foundation, and the Austrian Research Council Project S-41/06. Dr. Duchosal is a recipient of a Swiss National Foundation Grant.

\section{References}

1. Theofilopoulos, A. N., and F. J. Dixon. 1985. Murine models of systemic lupus erythematosus. Adv. Immunol. 37:269-390.

2. Madaio, M. P., A. Schattner, M. Schattner, and R. S. Schwartz. 1986. Lupus serum and normal human serum contain anti-DNA antibodies with the same idiotypic marker. J. Immunol. 137:2535-2540.

3. Uchigata, Y., B. S. Prabhakar, K. F. Salata, F. Ginsberg-Fellner, and A. L. Notkins. 1987. Human monoclonal multiple organ-reactive autoantibodies distinguished by mouse monoclonal anti-idiotypic antibodies: expression of idiotopes in humans with and without autoimmune disease. J. Immunol. 138:4218-4222.

4. Tonegawa, S. 1983. Somatic generation of antibody diversity. Nature (Lond.). 302:575-581.

5. Alt, F. W., K. Blackwell, R. A. DePinho, M. G. Reth, and G. D. Yancopoulos. 1986. Regulation of genome rearrangement events during lymphocyte differentiation. Immunol. Rev. 89:5-30.

6. Kofler, R., F. J. Dixon, and A. N. Theofilopoulos. 1987. The genetic origin of autoantibodies. Immunol. Today. 80:374-380.

7. Kofler, R., M. A. Duchosal, M. E. Johnson, M. T. Aguado, R. Strohal, G. Kroemer, and R. Faessler. 1987. The genetic origin of murine lupus-associated autoantibodies. Immunol. Lett. 16:265-272.

8. Kofler, R., R. M. Perlmutter, D. J. Noonan, F. J. Dixon, and A. N. Theofilopoulos. 1985. Ig heavy chain variable region gene complex of lupus mice exhibits normal restriction fragment length polymorphism. J. Exp. Med. 162:346-351.

9. Trepicchio, W., Jr., and K. J. Barrett. 1985. The Igh-V locus of MRL mice: restriction fragment length polymorphism in eleven strains of mice as determined with $V_{\mathrm{H}}$ and $\mathrm{D}$ gene probes. J. Immunol. 134:2734-2739.

10. Painter, C., M. Monestier, B. Bonin, and C. A. Bona. 1986. Functional and molecular studies of $\mathrm{V}$ genes expressed in autoantibodies. Immunol. Rev. 94:75-98.

11. Kofler, R., D. J. Noonan, D. E. Levy, M. C. Wilson, N. P. H. Møller, F. J. Dixon, and A. N. Theofilopoulos. 1985. Genetic elements used for a murine lupus anti-DNA autoantibody are closely related to those for antibodies to exogenous antigens. J. Exp. Med. 161:805-815.

12. Kofler, R., D. J. Noonan, R. Strohal, R. S. Balderas, N. P. H. Møller, F. J. Dixon, and A. N. Theofilopoulos. 1987. Molecular analysis of the murine lupus-associated anti-self response: involvement of a large number of heavy and light chain variable region genes. Eur. J. Immunol. 17:91-95.

13. Reininger, L., P. Ollier, P. Poncet, A. Kaushik, and J. C. Jaton. 1987. Novel $V$ genes encode virtually identical variable regions of six murine monoclonal anti-bromelain-treated red blood cell autoantibodies. J. Immunol. 138:316-323.

14. Shlomchik, M., D. Nemazee, J. Van Snick, and M. Weigert. 1987. Variable region sequences of murine IgM anti-IgG monoclonal autoantibodies (rheumatoid factors). II. Comparison of hybridomas derived by lipopolysaccharide stimulation and secondary protein immunization. J. Exp. Med. 165:970-987.

15. Arant, S. E., J. A. Griffin, and W. J. Koopman. 1986. $\mathrm{V}_{\mathrm{H}}$ gene expression is restricted in anti-IgG antibodies from MRL autoimmune mice. J. Exp. Med. 164:1284-1300.

16. Aguado, M. T., R. S. Balderas, R. L. Rubin, M. A. Duchosal, R. Kofler, B. K. Birshtein, D. S. Secher, F. J. Dixon, and A. N. Theofilopoulos. 1987. Specificity and molecular characteristics of monoclonal IgM rheumatoid factors from arthritic and non-arthritic mice. J. Immunol. 139:1080-1087. 
17. Trepicchio, W., Jr., and K. J. Barrett. 1987. Eleven MRL-lpr/ $l p r$ anti-DNA autoantibodies are encoded by genes from four $\mathrm{V}_{\mathrm{H}}$ gene families: a potentially biased usage of $\mathrm{V}_{\mathrm{H}}$ genes. J. Immunol. 138:2323-2331.

18. Trepicchio, W., Jr., A. Maruya, and K. J. Barrett. 1987. The heavy chain genes of a lupus anti-DNA autoantibody are encoded in the germ line of a nonautoimmune strain of mouse and conserved in strains polymorphic for this gene locus. J. Immunol. 139:3139-3145.

19. Shlomchik, M. J., A. H. Aucoin, D. S. Pisetsky, and M. G. Weigert. 1987. Structure and function of anti-DNA autoantibodies derived from a single autoimmune mouse. Proc. Natl. Acad. Sci. USA. 84:9150-9154.

20. Taylor, B. A., and L. Rowe. 1984. Genes for serum amyloid A proteins map to chromosome 7 in the mouse. Mol. Gen. Genet. 195:491-499.

21. Winter, E., A. Radbruch, and U. Krawinkel. 1985. Members of novel $\mathrm{V}_{\mathbf{H}}$ gene families are found in VDJ regions of polyclonally activated B-lymphocytes. EMBO (Eur. Mol. Biol. Organ.) J. 4:2861-2867.

22. Riley, S. C., S. J. Connors, N. R. Klinman, and R. T. Ogata. 1986. Preferential expression of variable region heavy chain gene segments by predominant 2,4-dinitrophenyl-specific BALB/c neonatal antibody clonotypes. Proc. Natl. Acad. Sci. USA. 83:2589-2593.

23. Kelley, D. E., L. M. Wiedemann, A. C. Pittet, S. Strauss, K. J. Nelson, J. Davis, B. Van Ness, and R. P. Perry. 1985. Nonproductive kappa immunoglobulin genes: recombinational abnormalities and other lesions affecting transcription, RNA processing, turnover, and translation. Mol. Cell. Biol. 5:1660-1675.

24. Nishioka, Y., and P. Leder. 1980. Organization and complete sequence of identical embryonic and plasmocytoma kappa V-region genes. J. Biol. Chem. 255:3691-3694.

25. Kelley, D. E., C. Coleclough, and R. P. Perry. 1982. Functional significance and evolutionary development of the 5'-terminal regions of immunoglobulin variable-region genes. Cell. 29:681-689.

26. Kwan, S., E. E. Max, J. G. Seidman, P. Leder, and M. D. Scharff. 1981. Two kappa immunoglobulin genes are expressed in the myeloma S107. Cell. 26:57-66.

27. Gearhart, P. J., and D. F. Bogenhagen. 1983. Clusters of point mutations are found exclusively around rearranged antibody variable genes. Proc. Natl. Acad. Sci. USA. 80:3439-3443.

28. Kofler, R. 1988. A new murine Ig $\mathrm{V}_{\mathrm{H}}$ gene family. J. Immunol. 140:4031-4034.

29. Strohal, R., G. Kroemer, G. Wick, and R. Kofler. 1987. Complete variable region sequence of a non-functionally rearranged kappa light chain transcribed in the non-secretor P3-X63-Ag8.653 myeloma cell line. Nucleic Acids Res. 15:2771.

30. Theofilopoulos, A. N., R. S. Balderas, L. Hang, and F. J. Dixon. 1983. Monoclonal IgM rheumatoid factors derived from arthritic MRL/Mp-lpr/lpr mice. J. Exp. Med. 158:901-919.

31. Pollard, K. M., J. E. Jones, E. M. Tan, A. N. Theofilopoulos, F. J. Dixon, and R. L. Rubin. 1986. Polynucleotide specificities of murine monoclonal anti-DNA antibodies. Clin. Immunol. Immunopathol. 40:197-208.

32. Okayama, H., and P. Berg. 1982. High-efficiency cloning of full-length cDNA. Mol. Cell. Biol. 2:161-170.

33. Queen, C., and L. J. Korn. 1984. A comprehensive sequence analysis program for the IBM personal computer. Nucleic Acids Res. 12:581-599.

34. Brodeur, P. H., and R. Riblet. 1984. The immunoglobulin heavy chain variable region (Igh-V) locus in the mouse. I. One hundred $I g h-V$ genes comprise seven families of homologous genes. Eur. J. Immunol. 14:922-930.

35. Cory, S., B. M. Tyler, and J. M. Adams. 1981. Sets of immunoglobulin $V_{k}$ genes homologous to ten cloned $V_{k}$ sequences: implications for the number of germline $V_{k}$ genes. J. Mol. Appl. Genet. 1:103116.
36. Corbet, S., M. Milili, M. Fougereau, and C. Schiff. 1987. Two $\mathrm{V}_{\mathrm{x}}$ germ-line genes related to the GAT idiotypic network (Abl and $\mathrm{Ab3} / \mathrm{Abl}^{\prime}$ ) account for the major subfamilies of the mouse $\mathrm{V}_{k}-1$ variability subgroup. J. Immunol. 138:932-939.

37. Even, J., G. M. Griffiths, C. Berek, and C. Milstein. 1985. Light chain germ-line genes and the immune response to 2-phenyloxazolone. EMBO (Eur. Mol. Biol. Organ.) J. 4:3439-3445.

38. Akolkar, P. N., S. K. Sikder, S. B. Bhattacharya, J. Liao, F. Gruezo, S. L. Morrison, and E. A. Kabat. 1987. Different $V_{L}$ and $V_{H}$ germ-line genes are used to produce similar combining sites with specificity for alpha $(1 \rightarrow 6)$ dextrans. J. Immunol. 138:4472-4479.

39. Juszczak, E., R. I. Near, M. L. Gefter, and M. N. Margolies. 1984. Complete heavy and light chain variable region sequence of the anti-arsonate monoclonal antibodies from $\mathrm{BALB} / \mathrm{c}$ and $\mathrm{A} / \mathrm{J}$ mice sharing the 36-60 idiotype are highly homologous. J. Immunol. 133:2603-2609.

40. Potter, M., J. B. Newell, S. Rudikoff, and E. Haber. 1982. Classification of mouse $V_{k}$ groups based on the partial amino acid sequence to the first invariant tryptophan: impact of 14 new sequences from IgG myeloma proteins. Mol. Immunol. 19:1619-1630.

41. Ollier, P., J. Rocca-Serra, G. Somme, J. Theze, and M. Fougereau. 1985. The idiotypic network and the internal image: possible regulation of a germ-line network by paucigene encoded Ab2 (antiidiotypic) antibodies in the GAT system. EMBO (Eur. Mol. Biol. Organ.) J. 4:3681-3688.

42. Sakano, H., K. Huppi, G. Heinrich, and S. Tonegawa. 1979. Sequences at the somatic recombination sites of immunoglobulin light-chain genes. Nature (Lond.). 280:288-294.

43. Shlomchik, M. J., A. Marshak-Rothstein, C. B. Wolfowicz, T. L. Rothstein, and M. G. Weigert. 1987. The role of clonal selection and somatic mutation in autoimmunity. Nature (Lond.). 328:805811.

44. Bothwell, L. M., M. Paskind, M. Reth, T. Imanishi-Kari, K. Rajewsky, and D. Baltimore. 1981. Heavy chain variable region contribution to the $\mathrm{NP}^{\mathrm{b}}$ family of antibodies: somatic mutation evident in a $\gamma_{2 \mathrm{a}}$ variable region. Cell. 24:625-637.

45. Ju, S. T., U. Siebenlist, and K. Kelly. 1984. Effects of $V_{\lambda}$ gene diversity on generation of antigen-specific lymphocytes. J. Immunol. 133:3378-3381.

46. Cohen, J. B., K. Effron, G. Rechavi, Y. Ben-Neriah, R. Zakut, and D. Givol. 1982. Simple DNA sequences in homologous flanking regions near immunoglobulin $\mathrm{V}_{\mathrm{H}}$ genes: a role in gene interaction? Nucleic Acids Res. 10:3353-3370.

47. Kurosawa, Y., and S. Tonegawa. 1982. Organization, structure, and assembly of immunoglobulin heavy chain diversity DNA segments. J. Exp. Med. 155:201-218.

48. Early, P., H. Huang, M. Davis, K. Calame, and L. Hood. 1980. An immunoglobulin heavy chain variable region gene is generated from three segments of DNA: $\mathrm{V}_{\mathrm{H}}, \mathrm{D}$ and $\mathrm{J}_{\mathrm{H}}$. Cell. 19:981-992.

49. Perlmutter, R. M., J. L. Klotz, M. W. Bond, M. Nahm, J. M. Davie, and L. Hood. 1984. Multiple $V_{H}$ gene segments encode murine antistreptococcal antibodies. J. Exp. Med. 159:179-192.

50. Dersimonian, H., R. S. Schwartz, K. J. Barrett, and B. D. Stollar. 1987. Relationship of human variable region heavy chain germ-line genes to genes encoding anti DNA autoantibodies. J. Immunol. 139:2496-2501.

51. Atkinson, P. M., G. W. Lampman, B. C. Furie, Y. Naparstek, R. S. Schwartz, B. D. Stollar, and B. Furie. 1985. Homology of the $\mathrm{NH}_{2}$-terminal amino acid sequences of the heavy and light chains of human monoclonal lupus autoantibodies containing the dominant 16/6 idiotype. J. Clin. Invest. 75:1138-1143.

52. Kabat, E. A., T. T. Wu, H. Bilofsky, M. Reid-Miller, and H. Perry. 1983. Sequences of Proteins of Immunological Interest. U. S. Department of Health and Human Services (PHS, NIH). 323 pp. 